Economics Development Analysis Journal 9(1)(2020)

\title{
Impact of Education on Poverty and Health : Evidence from Indonesia
}

\author{
Ade Marsinta Arsani ${ }^{1 凶}$, Bugi Ario ${ }^{2}$, Al Fitra Ramadhan ${ }^{3}$ \\ ${ }^{1,2,3}$ Padjajaran University \\ ${ }^{1}$ Central Statistics Agency of Indonesia \\ ${ }^{2}$ The Audit Board of the Republic of Indonesia \\ ${ }^{3}$ Indonesia's National Government Internal Auditor
}

$\begin{array}{ll}\text { Article } & \text { Abstract } \\ \text { Information } & \begin{array}{l}\text { As a classical problem, governments in developing countries should pay more attention to poverty, } \\ \text { its determiners, and its impact. Based on several previous studies, there is a strong relationship } \\ \text { between poverty, education, and health status. This study aims to scrutinize the relationship between } \\ \text { Hisrtory of Article : }\end{array} \\ \begin{array}{l}\text { Received October 2019 } \\ \text { Accepted December 2019 } \\ \text { Pusblished February 2020 }\end{array} & \begin{array}{l}\text { to reduce poverty. Therefore, to measure the relationship between them, monetary and non- } \\ \text { monetary models are used. By using Two Stage Least Square (2SLS) regression for monetary models } \\ \text { and logistic regression for non-monetary models, it is found that education significantly affects the }\end{array} \\ \begin{array}{l}\text { Keywords: } \\ \text { Impact,Education, } \\ \text { Health, Poverty }\end{array} & \begin{array}{l}\text { have significantly higher than the return from primary and secondary levels. Other control variables } \\ \text { such as age, gender, number of children, and residential, also have significant impacts on poverty } \\ \text { and household health status. Based on those results, the government should enhance and intensify } \\ \text { several programs such Program Indonesia Pintar (PIP), Bidikmisi, inclusive work environment, wage } \\ \text { equality, Pembinaan Kesejahteraan Keluarga (PKK), and Gerakan Masyarakat Sehat (GERMAS) to } \\ \text { eradicate poverty and elevate the public's health status through education and other supporting } \\ \text { factors. }\end{array}\end{array}$




\section{INTRODUCTION}

Poverty is a classic problem in developing countries, and also the attention of developed countries in the world. More than 700 million people, or $10 \%$ of the world population, still live in extreme poverty and is struggling to fulfil the most basic needs like health, education, and access to water and sanitation, to name a few (United Nations, 2019). As a follow up to the previous global agreement, which was the Millenial Development Goals (MDGs) or the Millennium Development Goals, the United Nations (UN) in September 2015 launched the SDGs or Sustainable Development Goals which is a global agenda that continues the efforts and achievements of the previous global agenda namely the MDGs. Poverty becomes the number one priority as it stated in Goal-1. Furthermore, it can be said that the SDGs is fully committed to the implementation of a national development agenda, mainly poverty alleviation program for all levels of society which will achieve substantial coverage of poor and vulnerable communities across the world by 2030 (Rassanjani, 2018). Ending poverty is not an easy way to do. Many aspects of life need to be integrated. Jeffrey Sachs on his book "The End of Poverty" said that one way to reduce poverty is the development of human capital especially in education and health (Sachs, 2005). This book supports Amartya Sen's book "Development as Freedom" which claims that shutting down the poverty should go through human capability (Sen A. , 1999).

Poverty is more than just simply financial distress as it inevitably part of lacking empowerment, knowledge, chance as well as to income and capital (Gounder \& Xing, 2012). Moreover, poverty has important role that influence macroeconomic policies that the governments endorse, as it generates a series of effects upon the fund distribution mechanism, affecting both the source and destination of public financial policies (Paraschiv, 2017).

The relationship between poverty and education is not simple. However, education brings people a healthier life and gives them smarter decisions about their life; for their children, their livelihoods, and the way they live. Education has a significant role for children, it provides chances to develop mentally, physically, and social awareness in them (ChildFund, 2019). The Unesco report claims that, if all adults completed secondary education, more people could be lifted out of poverty, global poverty rate would be reduced to more than halved. This report shows that education is so crucial to be the center to the achievement of the SDGs. Education can play a transformative role to bring people out from their poverty, but access and inclusion need to be improved by education policies (Unesco, 2003).

With education, people can improve their health and productivity. People with good education will have basic knowledge and skills, they will have a choice to have a job, starting from increasing productivity and raising income. Then education can break the vicious circle of poverty and social marginalization to improve the quality of life and social welfare (Ustama, 2009).

As well as education, health and poverty also have a strong correlation. Some research projects show that poverty affects people's health condition, while other projects provide enough proofs that health condition affects people's poverty status. Also, several research projects show both variables affect each other. Gounder and Xing (2012) said that health is one of the most important factors to wellbeing for alleviating poverty because good health relies on successful education and it is required for increasing productivity. Focusing on the effect of health on poverty, health affects people's poverty status in several ways. Directly, inadequate health condition, e.g infectious and neglected tropical diseases kill and weaken millions of the poorest and most vulnerable people each year and traps them in poverty (Roberts, 2018). Furthermore, the deterioration of health would have an instantaneous effect on productivity and/or income, which lead into changes in people's poverty status (Buddelmeyer \& Cai, 2009). Not only reducing productivity, but poor health condition also leads people (and their families) to sell assets to cover the costs of 
treatment (Roberts, 2017), in case that they have no insurance or receive no social protection from the government. This increases poverty and their vulnerability to shocks in the future. Indirectly, poverty is affected by health via several factors, one of them is via education. Well-educated people are more likely to select the healthy food needed to attain proper levels of nutrition, which have a positive impact on family health status and decreases mortality (Friedman, 2002). This result is necessary for gaining productivity to push economic growth and reduce poverty.

In Indonesia, people have rights and obligations of education. It is stated in The 1945 Constitution of the Republic of Indonesia that every Indonesian citizen has rights of having education and it is an obligation to have basic education (The 1945 Constitution of The Republic of Indonesia, 1945). Education plays an important role to make Indonesia stronger and more competitive in the world. However, there are several problems related to education in Indonesia: quality and access as well as the even distribution of well-trained teachers (Usaid, 2013).

Statistics Central defines poverty as an inability on the economic side to meet the basic needs of food and non-food that measured from the expenditure side (BPS, 2019). Regarding nonfood expenditure, one essential effort to eradicate poverty from a governmental standpoint is the investment in education, and indirectly in human capital, towards securing a sustainable future economic development (Ushadevi, 2001). A study conducted by Blankenau \& Camera (2009) confirms that knowledge and information to improve the overall quality of life and increase an individual's productivity, thus creating an environment prone to economic and technological growth. Studies show that governmental investments in public education have more social returns by comparison with added benefits at an individual's level, thus at a nation-wide level, the eradication of the vicious circle of poverty could be addressed by increasing the quality of public education (Casse \& Jensen, 2009). According to their studies, even though public expenditure in elementary education cannot be directly related to poverty alleviation or economic gain, investment in secondary and tertiary education programs and policies, in a lifecycle approach, become appealing to lower income people, allowing them to gain benefit from the distribution of the cost of education that initially a short-term income transfer into a longterm flow of taxes.

Attention on education also a tool to avoid the increasing number of child labor in which will help to reduce poverty rate. Compared to those in higher income countries, households in poor countries are often faced with circumstances where they cannot meet basic needs due to low income, this condition often lead to child labor. A Research conducted by Paraschiv (2017) confirms that there is a strong correlation between the number of severely deprived people and the educational attendance at primary level as people that have a very low income per capita in the family usually don't pay much attention to their family members education, as opposed to the income that family member could bring to the household, the parents tend to rather influence their children to work than study. She also assumed that there are some strong connections between the social and the economic factors both at micro and macro levels, the educational level at macroeconomic perspective and the income families are highly correlated that the child labor caused by the lack of money of the families affects children's education. While child labor might be causing drops in school enrollment, the human capital production is dwindled furthermore by shortened study time and years of school completion (Levin, Riffel, \& Anthony, 2000).

Many research projects have been published about the relationship between poverty, education and health. Research by Gounder \& Xing (2012) using monetary effects indicated formal education brings benefit to all income quartile households, however it cannot guarantee people with only primary education from falling into poverty. On the other hand, the results for non-monetary models showed that education gives a positive and significant impact on the tendency of the people to be involved in health prevention activities and in acquiring good 
housing facilities. Education is vital for a satisfying and rewarding life, and good health is a precondition for raising productivity. Education qualifies people to engage in healthy lifestyle, decision making and adequate health relies on successful education. So, education and health are necessary elements for economic growth and social development. These two factors roles as inputs and outputs give health and education central importance in economic development.

Although glorified as a paramount factor of poverty reduction, on the book "Poverty Eradication through Education" (Unesco, 2003) mentioned that education is a key but not a total cure. It needs to be supported by appropriate legislation, and enforced, to protect the poor, and to enhance their economic opportunities. Children have rights that must be respected, and they should have basic health, nutrition, shelter, and the opportunity to complete at least its primary education. The world's efforts must be consolidated towards this end. Many countries in the world has been concerned about poverty eradication, and a number of countries have made achievements in this direction. Having environment for learning conditions need to be put in place, then abject poverty can be eradicated. The poverty cycle can be broken, and the way is through education. To break the cycle, poorest children should be provided with education. It will be necessary to generate information about the children - where to find them, their characteristics and their needs - in order to inform better educational policies, plans, and program implementations. These programs will enhance individual freedom to develop their human capability.

Human capability is the basics of the development, so people should have their freedom to develop their human capability (Sen, 2000). This statement is supported by Sachs (2005) that said one of six ways to end poverty is through human capital, especially in education and health. Education can be used as a tool to elevate productivity. It is important to educate people. People with education have knowledge and skills to choose to get a job, so they are more productive to increase their income which can end the circle of poverty. Thus, education is an investment and an opportunity to compete in the world to have chances to have a better life in the future and support the development (Ustama, 2009).

As well as education, the strong correlation between health and poverty is shown by several research projects. Gounder \& Xing (2012) said that malnutrition, illness, too high fertility, and lack of health services lead household fall into. Data from around the world that collected by World Bank show that poorer regions tend to have health facilities that are of low quality and lack many basic medicines. Other projects also show that health and poverty have a reciprocal relationship. This result is supported by several studies. Sulistyowati (2013) said that an increasing number of government health expenditure gives the best result in inclining Gross Domestic Product (GDP) and reducing poverty. Another study conducted by Cai (2009) confirm that health condition has a positive and significant effect on wages. It means that people who have good health condition tend to get more income and their probability to fall into poverty will decline. Not only one way relationship, but health and poverty also have bidirectional or causal relationship.

However, these two relationships not occur simultaneously, the effect of poverty on health and the effect of health on poverty are likely to occur with a time difference (Buddelmeyer \& Cai, 2009). They found that compared to families headed by a person with good health, families headed by a person in illhealth are more likely to be in poverty. Then, to define the clear relationship between health and poverty, Lawson (2004) stated about dimensions of health/ill health that interact with components of poverty: Income poverty, nutrition and health; shelter and health; work environments and health; income poverty and health care costs; ill health and erosive livelihood strategies; and coping with vulnerability to ill health. Poverty and ill health interaction creating a basis for vicious cycles in which families gradually slide (because of stress or repeated minor shocks) or 
rapidly fall (due catastrophic shocks) into decreasing health status, declining incomes and assets, chronic poverty and, possibly, destitution or premature death. Health and education are parts of investment in human capital. These investments are substantive for developing countries to absorb modern technology and enhance productivity, in which turn leads to higher income and boost economic performance (Mankiw, Romer, \& Weil, 1992).

Due to that reason, the government of Indonesia pays attention to education and health. They allocate nearly a third of the government budget on education and health. As a result, in general poverty in Indonesia have fallen into under 10 percent. However, some provinces could not reach the same result. Although government allocated much money on an investment in human capital, the level of poverty in several provinces, e.g Papua, Papua Barat, and Aceh, inclined. Several factors that affect poverty and the ways they affect poverty make the control of poverty becomes challenging. This research is expected to scrutinize the relationship between education, health, and poverty and the way they affect each other to make the program priority scale in efforts to alleviate poverty.

\section{RESEARCH METHODS}

This research uses data from National Socio-Economic Survey in March 2016 from Statistics Indonesia. The models in this study are based on models in Gounder \& Xing (2012) with several modifications due to the availability. They developed models for poverty reduction in the form of monetary models and non-monetary models using evidence from Fiji. Fiji is described as a developing country and consists of an archipelago, similar to Indonesia.

The empirical models are used to examine the relationship between education and income earning as a proxy of poverty status. The model specifications are

$\ln$ Exp $=\beta_{0}+\beta_{1}$ School $_{i}+\beta_{2}$ Age $_{i}+\beta_{3}$ Age $_{i}^{2}+$ $\beta_{4}$ Female $_{i}+\beta_{5}$ Children $_{i}+\beta_{6}$ Rural $_{i}+u_{1 i}$ $\ln \operatorname{Exp}=\alpha_{0}+\alpha_{1} P_{R I M_{i}}+\alpha_{2} S E C_{i}+\alpha_{3} T E R_{i}+$ $\alpha_{4}$ Age $_{i}+\alpha_{5}$ Age $_{i}^{2}+\alpha_{6}$ Female $_{i}+$ $\alpha_{7}$ Children $_{i}+\alpha_{8}$ Rural $_{i}+u_{2 i}$

Aside from the question of ability the choice of years of schooling for an individual cannot necessarily be regarded as independent of expected earnings of that person. This problems will lead endogeneity problem issue. The problem of endogeneity issue is overcome by using instrumental variables for schooling in this study. Due to the limitation of the data, this study only adopt young parenthood as an instrumental variable. This variable captures the effect of schooling of young parenthood (YPi) to identify the individuals that have become head of households before reaching the age at which secondary school is normally culminated. The above noted issues are incorporated in the specification as below:

School $_{i}=\beta_{0}+\beta_{1}$ Female $_{i}+\beta_{2}$ Rural $_{i}+$ $\beta_{3} Y P_{i}+u_{1 i}$

Furthermore, two non-monetary models are used to analyze the effect of different channels such as education and health effects to alleviate poverty. In this study, health prevention status and sanitation status represent health variables. The estimations of models using logistic regression models. The models are :

$$
\begin{aligned}
& \text { HlthPVT }_{i}=b_{0}+b_{1} \text { School }_{i}+b_{2} \text { Age }_{i}+b_{3} \\
& \text { ln ln Exp }+b_{4} \text { Female }_{i}+b_{5} \text { Rural }_{i}+v_{1 i} \text {......(4) } \\
& \text { Sanitation }_{i}=c_{0}+c_{1} \text { School }_{i}+c_{2} \text { Age }_{i}+c_{3} \\
& \text { ln ln Exp }+c_{4} \text { Female }_{i}+c_{5} \text { Rural }_{i}+v_{2 i} \ldots \ldots \text {. (5) } \\
& \text { Sanitation }_{i}=d_{0}+d_{1} \text { PRIM }_{i}+d_{2} S E C_{i}+ \\
& d_{3} T E R_{i}+d_{4} A_{g e_{i}}+d_{5} \ln \ln \operatorname{Exp}+ \\
& d_{6} \text { Female }_{i}+d_{7} \text { Rural }_{i}+v_{3 i}
\end{aligned}
$$

Where ln Exp is natural logarithm of total household income; HlthPVT represent household engages in health prevention such as health insurance; Sanitation describes the availability of appropriate toilet facilities; School is the household head's completed years of schooling; YP indicates young parenthood; Age and Age 2 are age and squared of the household head's age; Female is a dummy variable that 
represents the female household head; Children is the number of household head's children living in that household; Rural is the dummy variable that represents the households in rural areas; PRIM is the household head's education with primary education; SEC is the household head's education with secondary education; TER is the household head's education with tertiary education; $\mathrm{u}_{1 \mathrm{i}}$ and $\mathrm{u}_{2 \mathrm{i}}$ are error terms.

\section{RESULTS AND DISCUSSION}

Appropriate technique of two-stage least square (2SLS) and logistic regression methodologies are applied to the data.

The estimated Two Stage Least Square (2SLS) monetary model results for aggregate education level or Eq. (1) show that the relationship between income and education. The School's coefficient is positive and significant, which indicate that the returns to education of household rise total household income by around $12 \%$.

This result support that attainment of education enhances the earning potential of individuals and consequently, the increased earnings will definitely help them to be out of poverty (Awan, Malik, Sarwar, \& Waqas, 2011). Moreover, the computed coefficient for the number of household's children living in that household (Children) is statistically significant and positive, which indicate an extra number of children living in that household increases household's total income by around $11.9 \%$.

Other regressors such as Age of the household head is positive and significant, while Age2 is negative and significant. This result indicate that Age have diminishing return effect, which means the effect of age to increase household's income could be positive up until, the age of around 59.5, then negative thereafter. Also, being a Female household head cause to a lower earnings level and the negative rural coefficient suggests that rural households are more likely and prone to be correlated with the living in poverty than urban households.

In terms of disaggregate education level (PRIM, SEC, TER) or Eq. (2), the estimated model results show an increase in income by 4.36
$\%$ for primary education, $31.6 \%$ for secondary education, and $72.7 \%$ for tertiary education. Thus, the return from TER education is significantly higher than the returns from PRIM and SEC levels, a finding also consistent with the view reported by Sacchidanand \& Biswas (2017) that increasing investment in education may lead a household from being poor to non-poor.

Table 1. The estimates of 2SLS empirical model

\begin{tabular}{|c|c|c|c|}
\hline Variables & $\begin{array}{l}\text { Eq. (1) } \\
\text { ln_Exp }\end{array}$ & $\begin{array}{l}\text { Eq. (2) } \\
\text { ln_Exp }\end{array}$ & $\begin{array}{l}\text { Eq. (3) } \\
\text { School }\end{array}$ \\
\hline School & $\begin{array}{l}0.120 * * * \\
(0.00404)\end{array}$ & & \\
\hline Prim & & $\begin{array}{l}0.0436 * * * \\
(0.00376)\end{array}$ & \\
\hline Sec & & $\begin{array}{l}0.316^{* * *} \\
(0.00429)\end{array}$ & \\
\hline Ter & & $\begin{array}{l}0.727 * * * \\
(0.00492)\end{array}$ & \\
\hline Age & $\begin{array}{l}0.0463^{* * *} \\
(0.000742)\end{array}$ & $\begin{array}{l}0.0380^{* * *} \\
(0.000511)\end{array}$ & \\
\hline Age2 & $\begin{array}{l}0.000389 * * * \\
(5.74 \mathrm{e}-06)\end{array}$ & $\begin{array}{l}0.000368^{* * *} \\
(5.00 \mathrm{e}-06)\end{array}$ & \\
\hline Female & $\begin{array}{l}-0.259 * * * \\
(0.00406)\end{array}$ & $\begin{array}{l}-0.311^{* * *} \\
(0.00322)\end{array}$ & $\begin{array}{l}- \\
0.692^{* * *} \\
(0.0199)\end{array}$ \\
\hline Children & $\begin{array}{l}0.119 * * * \\
(0.000975)\end{array}$ & $\begin{array}{l}0.127^{* * *} \\
(0.000920)\end{array}$ & \\
\hline Rural & $\begin{array}{l}-0.166^{* * *} \\
(0.00738)\end{array}$ & $\begin{array}{l}-0.276^{* * *} \\
(0.00231)\end{array}$ & $\begin{array}{l}- \\
1.709 * * * \\
(0.0130)\end{array}$ \\
\hline YP & $(0.007 / 50)$ & $(0.00231)$ & $\begin{array}{l}- \\
1.611 * * * \\
(0.0288)\end{array}$ \\
\hline Constant & $\begin{array}{l}12.89 * * * \\
(0.0692)\end{array}$ & $\begin{array}{l}14.31^{* * *} \\
(0.0138)\end{array}$ & $\begin{array}{l}12.21 * * * \\
(0.0315)\end{array}$ \\
\hline $\begin{array}{l}\text { R- } \\
\text { squared }\end{array}$ & 0.211 & 0.295 & 0.079 \\
\hline
\end{tabular}

Standard errors in parentheses

*** $\mathrm{p}<0.01,{ }^{* *} \mathrm{p}<0.05,{ }^{*} \mathrm{p}<0.1$

Source : Data processed, 2019

The gender (Female) covariate is negative and significant, the results are similar to research carried out by Meyer (2019) that female-headed households are less likely to receive more income if compared to male-headed households. The estimated Children coefficient is positive and significant. It suggests that families that have more children need a higher disposable income (Gounder \& Xing, 2012). 
Also, the results show that households that located in the urban areas are likely to have higher income than those in rural areas. The key finding from reduced form schooling Eq. (3) indicates that two instrumental variables are statistically significant at the convenient levels. Both living in rural areas (Rural) and young parenthood (YP) are negative and significant. Both rural and YP reductions are likely to discourage more children to attain schooling which can lead to lower income. Also, living in a female household head leads to reduce the years of education.

The estimates by schooling for the gender (Female), region (Rural), and young parenthood (YP) indicate declines in schooling which also lead to these households falling into poverty. The gender (female) coefficient which has negative and significant shows that female has less education than male. This result supports that female tends to retire from school than male due to household's decision in choosing male to continue schooling better than female (Kharisma, 2016).

The negative rural coefficient suggests that performance of rural households in education is lower than urban (Zhang, Li, \& Xue, 2015). The negative rural coefficient also suggests that rural households are more likely and prone to be correlated with the living in poverty than urban households. This result supports that level of poverty in rural areas are greater than in urban areas (Narsey, 2006). The young parenthood coefficient is negative and significant. Early marriage and pregnancy can be both a cause and consequence of school dropout (Bhircall, 2018).

On the other side, the estimated logit results for non-monetary models with aggregate and disaggregated education significantly affect health status. In terms of health prevention activities such as having a life and accident insurance policy, or medical and therapeutic appliances, and decision-making over households' living arrangement of having a living tenure with better sanitation facilities (i.e. toilets).

Besides than health prevention, sanitation is one of the most important parts to develop a better generation through escalating family members' health. Many factors affect sanitation and are affected by sanitation. In this paper, writers assess the factors affecting sanitation and their implications.

Tabel 2. The Estimates of Logistic NonMonetary Model Results

\begin{tabular}{llll}
\hline \multirow{3}{*}{ Variables } & Eq. (4) & Eq. (5) & Eq. (6) \\
Sealth_PVT & Sanitation & Sanitation \\
\hline \multirow{2}{*}{ School } & $0.0678^{* * *}$ & $0.121^{* * *}$ & \\
& $(0.00132)$ & $(0.00254)$ & \\
Srim & & & $0.185^{* * *}$ \\
Sec & & & $(0.0168)$ \\
& & & $0.914^{* * *}$ \\
Ter & & & $(0.0232)$ \\
& & & $1.231^{* * *}$ \\
Age & $0.0140^{* * *}$ & $0.0242^{* * *}$ & $(0.0369)$ \\
& $(0.000324)$ & $(0.000500)$ & $(0.000461)$ \\
ln_Exp & $0.220^{* * *}$ & $0.924^{* * *}$ & $0.899^{* * *}$ \\
& $(0.00644)$ & $(0.0110)$ & $(0.0103)$ \\
Female & $0.0749^{* * *}$ & $0.231^{* * *}$ & $0.194^{* * *}$ \\
& $(0.0119)$ & $(0.0189)$ & $(0.0173)$ \\
Rural & $-0.0595^{* * *}$ & $-1.288^{* * *}$ & $-1.270^{* * *}$ \\
& $(0.00839)$ & $(0.0165)$ & $(0.0157)$ \\
Constant & $-4.020^{* * *}$ & $-11.67^{* * *}$ & $-10.64^{* * *}$ \\
& $(0.102)$ & $(0.175)$ & $(0.164)$ \\
& & & \\
Observations & 278,146 & 278,146 & 291,414 \\
\hline
\end{tabular}

Standard errors in parentheses

*** $\mathrm{p}<0.01,{ }^{* *} \mathrm{p}<0.05,{ }^{*} \mathrm{p}<0.1$

Based on table 2, education of household head has a great impact on the household's decision to engage in better sanitation. The higher the education of household head, the greater the tendency to have appropriate sanitation such as toilets. Several previous studies support this result. Furnee, Groot, and Brink (2008) show that a year of education improves the Quality Adjusted Life Years. World Development Report 2003 also show a similar thing. According to data from around the world, United Nations (2003) finds that a cross-country comparison over time shows that increases in educational attainment precede improvements in health status. The disaggregated household head's education levels (PRIM, SEC, TER) estimates are significantly supporting the view that all educational levels are essential in changing the decisions of people concerning their health. Not only education but wealth also significantly affects the household sanitation. 
The higher the income, the more they realize to have good sanitation facilities.

The other factors such as age, household head's gender, and residency have a significant effect on sanitation. The household with a female as household heads are more likely to engage in providing better sanitation facilities compared to their male counterparts. This result is similar to the finding of Gounder and Xing (2012). These findings are supported by the facts that in most societies, women have the prime responsibility for the management of household water supply, sanitation, and health. The provision of hygiene and sanitation are often considered women's tasks. Women are promoters, educators and leaders of home and community-based sanitation practices (Wendland, Yadav, Stock, \& Seager, 2017).

Furthermore, the age of the household heads (either for responsibility or obligation) is a significant predictor of health decisions or outcomes in which older household heads tend to develop better sanitation than young household heads (who usually face less risk of acquiring illnesses).

The last predictor is residency. The result shows that people living in rural areas tend to have no proper sanitation compared to those who live in an urban area. Using logistic coefficient interpretation, the likelihood to have appropriate sanitation in the urban area is 3.6 times higher than their rural counterparts. Usually, the rural area faces greater challenges in the efforts to provide safe water for proper health and sanitation (Omarova, Tussupova, Hjorth, Kalishev, \& Dosmagambetova, 2019). All of those results above show that, whether in a small country like Fiji or in a large country like Indonesia, education has a significant impact both on poverty and health. It means that governments in any countries should pay more attention to education and all of their supporting variables in order to accelerate poverty reduction and improve public health condition.

The economic analysis of both monetary and non-monetary models for Indonesian's earnings and education-health relationship supports the view that income, education, and health are connected. Education plays an important role to achieve higher income and the knowledge to acquire higher health awareness. The findings provide strong evidence for Indonesia government and households to invest their resources in education. Education is negatively linked with poverty and higher levels of education would aid in the alleviation of poverty (Awan, Malik, Sarwar, \& Waqas, 2011). As higher educational level enhances the possibilities of individual to obtain higher earnings. Ongoing government programs that increase access to education such as Program Indonesia Pintar (PIP) and Bidikmisi must be continued especially to those in the urban and rural poor households and if it is possible, the government should increase the number of beneficiaries.

Although the equality level of education between male and female is achieved, the disparity in income between male and female still exists. Addressing wage inequality may also reduce poverty. Hence, programs to enhance gender equality, such as creating inclusive employment opportunities, should be increased. Also, gender equality still needs additional policy improvement, government should provide a suitable employment environment for the female because they are almost half segment of our society and their well-being will definitely help us in poverty reduction (Awan, Malik, Sarwar, \& Waqas, 2011).

Disparity happens not only by gender, but also by residential. Addressing income inequality for rural and urban areas would also reduce poverty through provision of entrepreneurship training, as rural people would have more job creation and eventually create employment opportunities for others.

Not only affect household wealth status, but education also increases the individual awareness about health prevention, health risk and better sanitation. Living with good health engage activities in attaining higher education and income. Thus, these factors may become the main structure in constructing people out of poverty. A rise in the number of job opportunities may bring people to live a healthy lifestyle since 
it gives them choices to work in higher formal employment which give higher salary.

Gender should be considered when taking policy about health. It is important since gender equality has the important role to maintain health in which has strong correlation to poverty. As living in households headed by men and in rural areas tends to have lower health prevention and sanitation, government should encourage health education among people in rural areas, not only for women as mother via Pembinaan Kesejahteraan Keluarga (PKK) programs, but also for all of family members such as via Gerakan Masyarakat Sehat (GERMAS) program. More intensive programs are really needed.

\section{CONCLUSION}

The analysis of monetary and nonmonetary models show the relationship between poverty, education and health in Indonesia. Education can prevent people from falling into poverty and give knowledge to a healthy life. As the main variable, the returns of education to household rise total household income. In disaggregated form, the returns from tertiary education have significantly higher than the returns from primary and secondary education levels. It means that to achieve higher income, people should escalate their education level. Because education is affected by other variables such as the age of first married and residency, the government should also pay attention to those variables to optimize the benefit of education on wealth status. Not only affect poverty status, but education also has a great impact on health status in which theories also determine poverty status. Both aggregated and disaggregated education affect the health factors for reducing poverty in terms of health prevention activities such as having a life and accident insurance policy and decision-making over households' living arrangement of having a living tenure with better sanitation facilities (i.e. toilet). As education cannot stand separately from other factors such as demographic variables and gender, the government should give serious attention to those conditions to achieve maximum benefit. Several programs such as Program Indonesia Pintar
(PIP), Bidikmisi, inclusive work environment, wage equality, Pembinaan Kesejahteraan Keluarga (PKK), and Gerakan Masyarakat Sehat (GERMAS), should be enhanced and intensified to accelerate the elevation of health status and the eradication of poverty.

\section{REFERENCES}

Awan, M. S., Malik, N., Sarwar, H., \& Waqas, M. 2011. Impact of Education on Poverty Reduction. International Journal of Academic Research, Vol.3 No. 1 January.

Baros, W. A. 2015. Factors Affecting Health Insurance Ownership. Indonesian Health Policy Journal, 2025.

Bhircall, J. 2018. Early Marriage, Pregnancy and Girl Child School Dropout. K4D.

Blankenau, W., \& Camera, G. 2009. Public Spending on Education and the Incentives for Student Achievement. Economica New Series Vol.303, 505-527.

Central Statistics Agency 2019. https://www.bps .go.id/subject/23/kemiskinan-dan-

ketimpangan.html. Retrieved from https://www.bps.go.id.

Buddelmeyer, H., \& Cai, L. 2009. Interrelated Dynamics of Health and Poverty in Australia. IZA Discussion Paper Series.

Cai, L. 2009. Effects of Health on Wages of Australian Men. Economic Record, 290-306.

Casse, \& Jensen. 2009. Do We Undestand the Lingkages Between Economic Growht, Poverty Targets and Poverty Reduction? Review of African Political Economy Vol 36 No. 122, 539-553.

Chan, L., Hart, L. G., \& Goodman, D. C. 2006. Geographic Access to Health Care for Rural Medicare Beneficiaries. National Rural Health Association.

ChildFund. 2019. Poverty and Education. Retrieved from https://www.childfund.org/: https:// www.childfund.org/poverty-and-education/

Friedman, H. 2002. Health Psychology. New Jersey: Pearson Education.

Furne, C. A., Groot, W., \& Brink, H. M. 2008. The health effects of education: a meta-analysis. European Journal of Public Health, 417-421.

Gounder, R., \& Xing, Z. 2012. Impact of Education and Health on Poverty Reduction: Monetary and Non-Monetary Evidence from Fiji. Economic Modeling, 787-794. 
Groot, W., \& Brink, H. M. 2007. The Health Effects of Education. Economics of Education Review, $186-200$

Bertakis, K. D., Azari, R., Helms, L. J., Callahan, E. J., \& Robbins, J. A. (2000). Gender Differences in the Utilization of Health Care Services. Journal of Family Practice, 49(2), 147-152.

Kharisma, B. 2016. Income Shocks And Human Capital Investment In Indonesia. Universitas Gajah Mada.

Laaksonen, M., Prattala, R., Helasoja, V., Uutela, A., \& Lahelma, E. 2003. Income and Health Behaviours. Evidence from Monitoring Surveys Among Finnish Adults. Journal of Epidemiol Community Health.

Lawson, D. 2004. Health, Poverty and Poverty Dynamics in Africa. IV Mediterranean Seminar on International Development. Manchester.

Levin, B., Riffel, J., \& Anthony. 2000. Current and Potential School System Responses to Poverty. Canadian Public Policy/Analyse de Politiques Vol.26 No.2 June, 183-196.

Mankiw, G., Romer, D., \& Weil, D. 1992. A contribution to the empirics of economic growth. Quarterly Journal of Economics, 407-437.

Narsey, W. 2006. Report on the 2002 - 2003 household income and expenditure survey. Suva: Vanuavou Publications.

Omarova, A., Tussupova, K., Hjorth, P., Kalishev, M., \& Dosmagambetova, R. 2019. Water Supply Challenges in Rural Areas: A Case Study from Central Kazakhstan. International Journal of Environmental Research and Public Health.

Paraschiv, C. I. 2017. The Role of Education in Poverty Alleviation. International Finance and Banking Conference FI BA ( XV Edition), 115132.

Rassanjani, S. 2018. Ending Poverty: Factors That Might Influence the Achievment of Sustainable Development Goals (SDGs) in Indonesia. Journal of Public Administration and Governance Vol. 8 No. 3.

Roberts, S. 2017. The Cycle of Poverty and Poor Health. Retrieved from Health Poverty Action: https://www.healthpovertyaction.org/newsevents/the-cycle-of-poverty-and-poor-health/

Roberts, S. 2018. Key Facts: Poverty and Poor Health. Retrieved August 29, 2019, from Health Poverty Action: https://www.health povertyaction.org/news-events/key-factspoverty-and-poor-health/
Sacchidanand, M., \& Biswas, S. C. 2017. The Role of Educaiotn in Poverty Alleviation: Evidence from Bangladesh. Journal of Economics and Sustainable Development, Vol.8 No.20.

Sachs, J. 2005. The End of Poverty. New York: Penguin Press.

Sen, A. 1999. Development as Freedom. New York: Random House Inc.

Sen, A. 2000. Development as Freedom. New York: Anchor Books.

Sulistyowati, N. 2013. The Effect of Educational, Health, Infrastructure Expenses on The Workforce Employment and Poverty. International Journal of Administrative Science and Organization, 121-128.

The 1945 Constitution of The Republic of Indonesia. 1945. The 1945 Constitution of The Republic of Indonesia. Indonesia.

United Nations. 2019. https://www.un.org/ sustainable development/poverty/. Retrieved from https://www.un.org/.

Unesco. 2003. Poverty Eradication through Education. France: Unesco.

United Nation. 2003. World Development Report 2003. New York: United Nation.

Usaid. 2013. Reflection on Education in Indonesia. Retrieved from http://www.prestasi-iief.org: http://www.prestasi-iief.org/index.php/ english/feature/68-reflections-on-educationin-indonesia

Ushadevi, M. 2001. Poverty Database in Education: Strategies for Monitoring Poverty Reduction. Economic and Political Weekly Vol.36 N0.29, 2779-2783.

Ustama, D. D. 2009. The Role of Education in Poverty Alleviation. Dialogue Journal of Administrative Sciences and Public Policy, 1-12.

Wendland, C., Yadav, M., Stock, A., \& Seager, J. 2017. Gender, Women and Sanitation. In J. R. B.Jiménez-Cisneros, Global Water Pathogen Project (pp. 3-6). Michigan: Michigan State University.

Wijayanto, W. P. 2017. Relationship of Knowledge and Economic Capability of the Community to Accessibility of BPJS. Aisha Journal: Journal of Health Sciences 2, 131 - 140.

Zhang, D., Li, X., \& Xue, J. 2015. Education Inequality between Rural and Urban Areas of the People's Republic of China, Migrants' Children Education, and Some Implications. Asian Development Review, 196-224. 